\title{
Contested destinies: Aboriginal advocacy in South Australia's interwar years
}

\author{
Robert Foster
}

\section{Introduction}

In the interwar years, as protection policies took hold across Australia, Aboriginal political organisations and advocacy groups emerged to protest and demand rights and freedoms. Among the better known of the Indigenous-led organisations were Fred Maynard's Australian Aboriginal Progressive Association (AAPA) in New South Wales, and William Cooper's Australian Aborigines' League in Victoria. These were regional organisations fighting mostly local issues such as the injustices of life 'under the Act', or for better access to land and resources. However, they also engaged national issues, as exemplified by William Cooper's Petition to the King, which was circulated throughout the country and called for reserved seats for Aboriginal people in federal parliament. ${ }^{1}$ More influential, however, were the white-run advocacy groups. The Association for the Protection of Native Races, established in 1911, had a national perspective and, among other things, sought greater federal control of Aboriginal affairs. ${ }^{2}$ The National Missionary Council, established in the mid-1920s, was a platform for many of the mainstream churches. ${ }^{3}$ More locally were groups such as the Australian Aborigines Ameliorative Association in Western Australia and the Victorian Aboriginal Group in Melbourne. As Attwood has observed, these were highly paternalistic organisations, who saw themselves working 'for' Aboriginal people 'rather than through them'. ${ }^{4}$ This was certainly true of South Australia's long-

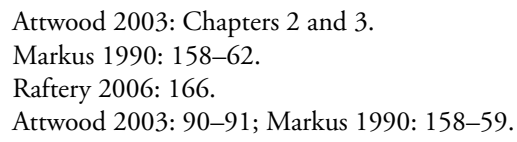


established Aborigines' Friends' Association (AFA), which Attwood has described as one of Australia's 'most politically conservative' missionary organisations. South Australia also gave rise to one of the most radical of the nation's advocacy groups, the Aborigines' Protection League. Established in 1925, its central issue was a petition campaign for the establishment of Aboriginal states - imagined essentially as Home Lands governed by Aboriginal people themselves.

A number of scholars have examined the 'Model State' campaign: Michael Roe drew scholarly attention to it with a brief article in 1986 in which he focused primarily on the nature of the Petition itself; 5 in 1999, Kevin Blackburn wrote a detailed analysis of it from a political history perspective; ${ }^{6}$ Ben Silverstein has explored it through the prism of Lord Lugard's model of Indirect Rule; while others have looked at it in the context of Commonwealth Aboriginal policy. ${ }^{7}$ My intention in this paper is not to revisit the Model Aboriginal State campaign, per se, but to examine the Aborigines' Protection League's broader political agenda. The league's campaign for autonomous Aboriginal States was part of a more general advocacy of land rights and self-determination - a radical, even utopian, agenda in an era dominated by paternalistic protection policies. In South Australia, the most vocal advocate of the latter policy was the AFA, which was not only well-resourced, but had a direct influence on the shaping of protection policy through its dominance on the state's Advisory Council for Aborigines. ${ }^{8}$ The purpose of this paper is to examine the Protection League's challenge to the association's stranglehold on public debate about Aboriginal policy and administration, from its formation in the mid-1920s, through to its dissolution in the late 1930s, when the 'New Deal' saw the policy of protection give way to assimilation.

\section{Aborigines' Friends' Association and state 'protection' policy}

South Australia Aborigines Protection Act 1911 was passed well over a decade after most states had put comparable legislation in place. ${ }^{9}$ The Chief Protector at the time the Act was passed was William Garnett South, a former Mounted Constable who had served on the frontiers of Central Australia in the 1890s. As I have argued elsewhere, South's principal concern was the growth of the state's 'half-caste' population; he wanted to remove Aboriginal people of mixed descent from Aboriginal camps, disperse the mixed-descent population of missions into

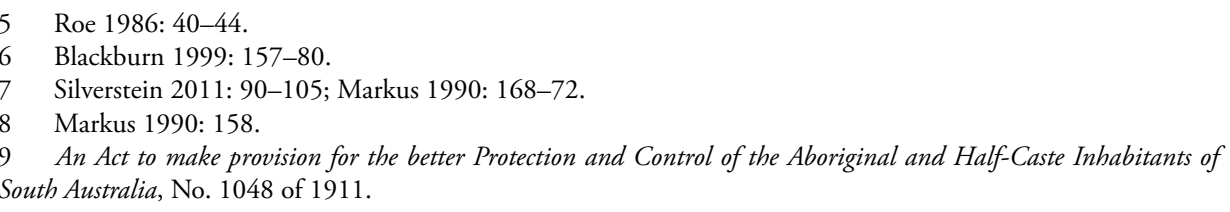


the general community, and replace the existing network of privately run missions with state-run 'Industrial Institutions' ${ }^{10} \mathrm{He}$ believed that they 'must inevitably be merged into the general population' and that 'nothing should be left undone that will help to convert these people into useful members of the community instead of allowing them to grow up dependents'. ${ }^{11}$

A royal commission into the operation and management of the state's missions was established in 1913, and it recommended that the state's four missions be taken over by the government and administered by the Aborigines Department. In the end, only the two southern missions were taken over: Point Pearce on Yorke Peninsula in 1915, and Point McLeay in 1916. Point McLeay was one of the state's oldest missions, established in 1859 on the shores of Lake Alexandrina by an interdenominational Christian group calling itself the Aborigines' Friends' Association (AFA). ${ }^{12}$ By the close of the nineteenth century, with a growing population and insufficient land, the association was finding it increasingly difficult to make the mission financially viable and supported the government intervention. ${ }^{13}$

The government takeover of the mission at Point McLeay in 1916 could conceivably have sounded the death knell of the association, but it rebounded with surprising energy. The man most responsible for this resurgence was John Henry Sexton, a Baptist Minister who became 'Missionary Secretary' of the association in 1912. ${ }^{14}$ Graham Jenkins, in his history of the association to 1915, describes Sexton as someone who had a 'penchant for organising things - particularly other people', and claims that he 'gained virtual control of the AFA' when he became general secretary in $1913 .{ }^{15}$ Sexton was socially and politically well-connected. In 1886, he married the daughter of Thomas Playford, state premier, federalist and senator in the first federal parliament. ${ }^{16}$ Under Sexton's influence, the association ambitiously broadened its ambit of activities and the reach of its influence. ${ }^{17}$

In the first instance, the association continued to fund a full-time missionary at Point McLeay. The government takeover of the Point Pearce mission, on Yorke Peninsula, opened up another opportunity; with no comparable body maintaining an involvement in the community, the AFA took an interest in the spiritual welfare of the residents. Their activities included providing nurses at both government stations, as well as contributing to the provision of medical facilities. ${ }^{18}$ In the

10 Foster 2000: 15.

11 Report of the Protector of Aborigines for the year ending June 20, 1912, South Australian Parliamentary Papers

(SAPP): 7

12 Jenkins 1976: 3-20.

13 Jenkins 1976: 333-60.

14 Jenkins 1976: 328.

15 Jenkins 1976: 328-29.

16 Edgar 1988.

17 Jenkins 1976: 328-29.

18 See Aborigines' Friends' Association (AFA), Annual Reports, for the late 1920s and early 1930s. 
mid-1920s, it expanded its reach into Central Australia. In the 1920s, the association became interested in E.E. Kramer's 'Camel Caravan'. Kramer was a self-appointed missionary, who for some years had been evangelising in Central Australia. ${ }^{19}$ The association was impressed by his work and began funding his activities. ${ }^{20}$ As this assistance demonstrates, the association also served as a general funding body, albeit at a modest level, supporting a variety of missionary and philanthropic causes. ${ }^{21}$ By 1926, the association had also became an active participant at the annual National Missionary conference, with Sexton attending regularly and contributing to the development of policy. ${ }^{22}$

Significantly, the association also acquired a direct influence on the formulation of government policy. When South Australia passed its Aborigines Protection Act in 1911, it left executive authority to the Chief Protector of Aborigines, in contrast to other states, which established Protection Boards. The 1913 royal commission recommended the establishment of a Board, and the association lobbied the government to act on the recommendation. ${ }^{23}$ The Minister of Public Works, in whose department the Protector's Office was situated, agreed and in January 1918 an 'Advisory Council for the Aborigines' was formally established. ${ }^{24}$ The minister was well-disposed toward the AFA and he allowed the seven-member committee to be drawn entirely from the association's general committee. This included the association's president, Thomas Fleming, and their secretary, Henry Sexton, who was elected Chairman of the Advisory Council. Even the parliamentary representative on the council, MLC John Lewis, was a member of the AFA. All members served in an honorary capacity, but the government paid all expenses connected with their work. ${ }^{25}$ Although membership changed over time, the council was dominated by AFA members until the 1930s. However, while the council had unparalleled influence, it had surprisingly little power, its formal role was to 'make recommendations' to the minister, with executive authority under the Act remaining with the Chief Protector. Sexton later recalled that the council was at its most effective in its early years - a time, one would suggest, when the council and the Chief Protector were singing from the same hymn sheet of 'protection'. ${ }^{26}$ The essence of 'protection' policy is captured in the two words most commonly found in the longer title of the relevant Acts: 'protection' and 'control'. In these Acts, the government secured

19 Markus 2000.

20 See AFA, Annual Reports, for the 1920s for details of Kramer's work and his association with the AFA.

21 In 1936, for instance, it gave out $£ 185$ to 28 different missionary causes, see AFA, Annual Report, 1936, p. 18.

22 AFA, Annual Report, 1926: 3-5.

23 South Australia, Royal Commission 1913: vii-viii; AFA, Minutes, 17 February and 26 October 1917, SRG 139/2-6.

24 Regulations under the Aborigines Act, 1911, South Australian Government Gazette (SAGG), 24 January 1918: 141.

25 Appointments to the first Council, $S A G G, 31$ January 1918: 182.

26 J.H. Sexton, The Advisory Council of Aborigines: The Origin of the Board: 7, in AFA, Correspondence files, SRG $139 / 1 / 400$. 
to itself coercive controls over the lives of Aboriginal people, and especially the children over whom it became de facto parent. It heightened the level of segregation on government and mission-run settlements, where it endeavoured to implement programs of education and training designed to prepare the children for life off the missions and in the broader community. ${ }^{27}$ This was a policy pursued by the Protector of Aborigines, advocated by the AFA and, for a time, mediated by the Advisory Council of Aborigines.

In pursuit of his policy to push people off the 'mission' and into the general community, the Chief Protector adopted two strategies. First, regulations were introduced to make life on the government stations increasingly unattractive, with penal provisions for a range of petty offences. ${ }^{28}$ Second, he developed a Bill that would give him authority to take children who had reached school-leaving age and place them under the authority of the state Children's Department, where they would be given 'practical training' until they reached their majority. ${ }^{29}$ The Training of Children Act became law in 1923, and although South died shortly before the Act became law, his successor, Francis Garnett, previously superintendent at Point Pearce, supported the policy. The AFA also supported it; indeed, through their influence on the council, they may have helped develop it. For a number of years before the Act was passed, the association had been advocating the establishment of 'Children's Homes' on the government stations - effectively dormitories - where the children would be 'trained' and taught 'discipline. ${ }^{30}$ The new Protector supported the proposal, believing it would better prepare the children for their transition to the authority of the state Children's Department. ${ }^{31}$ The Aborigines Department went to great lengths to prepare for this change, including drawing up lists of children they regarded as suitable for removal.

The implementation of the Act proved a disaster for the government. In March 1924, the state Children's Council ordered the removal of a baby from her mother, a resident at the Point McLeay station. The Children's Department officer contrived to take the baby from her mother in what proved to be a fraught and very public scene as she disembarked from her train at the Adelaide Railway Station. ${ }^{32}$ The removal became headline news. Aboriginal people, who had already indicated their opposition to the Act, protested against the removal, and the action was roundly condemned in the press. The mother was interviewed; she pointed out that her brothers had patriotically served in the war, and asked, 'is there to be one law for the white

27 Edgar 1988.

28 Foster 2000: 21.

29 Raynes 2009: 5-7.

30 The Annual Reports of the AFA from 1918 through until the mid-1920s regularly called for their establishment.

31 Report of the Chief Protector of Aboriginals for the year ended 30 June 1920, South Australian Parliamentary

Papers, 1920: 103.

32 Raynes 2009: 7. 
people, and another for the black?'33 C.E. Taplin, son of Point McLeay's founding missionary and, at this time, President of the AFA, wrote to Protector Garnett describing the removal as an 'outrage'. ${ }^{34}$ Sexton, Secretary of the AFA and Chairman of the Advisory Council, wrote that he thought the 'hasty attempt to put the new Act into force' would 'recoil' on the department and sought an explanation from the Protector. The Protector agreed that the removal was 'tactless and unfortunate', and not what the Act was primarily designed to facilitate. The child was returned to its mother. ${ }^{35}$ As the Protector noted in his annual report, the Act was suspended because of 'native sentiment being opposed to it'. ${ }^{36}$ The elaborate plan entailed in the Training of Children Act to 'transition' Aboriginal children from the government stations via the state Children's Department into the broader community, and which both Garnett and Sexton supported, was rendered a 'dead letter'. ${ }^{37}$ The underlying policy of 'protection', however, remained in place, and continued to be advocated by the AFA. A collateral effect of the episode was the damage it did to the relationship between the Protector and the Advisory Council. As Sexton himself conceded, over time the council was marginalised, with the minister seeking advice directly from the Protector and increasingly ignoring the council. ${ }^{38}$

\section{The Aborigines' Protection League and the Model State campaign}

In early 1924, just as the controversy over the Training of Children Act was unfolding, Col. J.C. Genders, a businessman, was appointed to the General Committee of the AFA. Genders was 66 years of age at the time, manager of an Adelaide accountancy firm, a Freemason, member of the Australian Natives' Association, and head of the Justices' Association..$^{39}$ We get some insight into his interests and preoccupations through a small monthly newspaper called Daylight, which he began publishing in 1919. Self-described as a 'journal for thinking and progressive farmers', it carried stories about grain prices and agricultural policy, but also served as a vehicle for his own causes. It reveals Genders as a Christian socialist and an internationalist; he was, for instance, interested in the League of Nations and an advocate of Esperanto. Why he suddenly decided to become involved in Aboriginal advocacy is unclear as up to

\footnotetext{
33 Foster 2000: 23-24.

34 C.E. Taplin to F. Garnett, 21 April 1924, AFA, Correspondence files, SRG 139/1/400.

35 Garnett to Sexton, 2 and 7 May 1924, AFA, Correspondence files, SRG 139/1/400.

36 Report of the Chief Protector of Aboriginals for the year ended 30 June, 1924, SAPP: 138.

37 Garnett to Sexton, 2 May 1924, AFA, Correspondence files, SRG 139/1/400.

38 J.H. Sexton, The Advisory Council of Aborigines: The Origin of the Board: 7-9, AFA, Correspondence files, SRG $139 / 1 / 400$.

39 Blackburn 1999: 168. See also Burgess 1907: 556-7. The Australian Natives' Association was founded in Melbourne in the 1870 s, with branches being subsequently established in all other Australian colonies. Its membership was restricted to men born in Australia, and it promoted 'nationalist' causes, most famously, Australian federation. The Justices' Association was founded in South Australia in 1898 to support the work of Justices of the Peace.
} 
the time he joined the association, Daylight published almost nothing on Aboriginal matters. Once a member, Genders regularly attended association meetings and, in the aftermath of the removal controversy, accompanied Taplin on a visit to Point McLeay. ${ }^{40}$

His first contribution to AFA business came in a late February meeting in 1925. Genders asked that the committee convene a round-table conference to discuss the following resolution that he wanted to present to the upcoming annual general meeting:

That a petition be presented to Federal Parliament praying for the creation of a separate state in Northern Australia to be called the Australian Black State, The Australian Zion State, or some more appropriate name, citizenship in which to be restricted to Australian Natives ... ${ }^{41}$

The minutes politely record that discussion of the matter was deferred to a later date. The annual general meeting went ahead a week later, at which Sexton spoke at length about the 'Problem of the Half-Caste' and tried to breathe life back into the plans to establish 'Children's Homes' and revive the Training Scheme. ${ }^{42}$ Genders resigned from the association a week before the AGM and immediately began to promote his scheme for a 'Model Aboriginal State'. He outlined his proposal in letters to the press and published a lengthy explanation of the scheme in his newspaper Daylight. The time had come, he wrote, to save 'the fast dying Australian Aboriginal Races', and 'redeem' the country's mistakes by creating 'a separate State in Northern Australia called the Australian Black State'. Citizenship would be restricted to Aboriginal people; a 'Native Tribunal', initially assisted by a government resident, would govern the state, but there was to be no interference 'with the Laws and Customs of the Natives'. ${ }^{43}$ Having floated his plan, Genders set about organising his 'Round Table Conference' for 13 March 1925. ${ }^{44}$ Prominent attendees were Dr Herbert Basedow and Capt. S.A. White, the former was an anthropologist and the latter a naturalist, and both prominent members of Adelaide's scientific community. Only a few years previously, they had been pivotal to the successful campaign for the establishment of the North-West Reserve, which they hoped would protect the Aboriginal tribes of the region from forced cultural change.

Over the course of 1925, a series of meetings were held to further develop the proposal. In July, a subcommittee was appointed to draft a 'manifesto and petition'. Aside from Genders, it included Basedow and White, Rev. J.C. Jennison, who had also been a key supporter of the North-West Reserve campaign, and C.E.

40 AFA, Minutes, 11 April 1924, SRG 139/2-6.

41 AFA, Minutes, 29 January 1925, SRG 139/2-6.

42 Advertiser, 18 February 1925: 10.

43 Daylight, 28 February 1925: 846.

44 Register, 14 March 1925: 11. 
Taplin, who, only a month before, had been President of the AFA. ${ }^{45}$ By March of the following year the final version of the Petition and Manifesto had been published. The key element remained a call to establish a 'Native State' to ultimately be managed by a native tribunal, with the exception of 'authorized missionaries, teachers and agricultural instructors', no one was permitted to enter the State without the authority of the tribunal, but Aboriginal people were permitted to come and go as they pleased. A new element was added, that they have representation in federal parliament, along New Zealand lines. The Manifesto elaborated the details of the plan explaining that this was to be a 'Model Aboriginal State' and, if it was successful, others 'would surely follow' and that 'the growth of a sense of nationhood would be a great incentive'. In this conception, the Aboriginal state was imagined as developing toward an equivalent status to the existing states of the Commonwealth, eventually enjoying its own constitution, with its citizens governing themselves in their own country. The precise location of the first state was not defined, but was imagined that it would be an existing tribal territory somewhere in Arnhem Land. As the campaign progressed, its supporters endeavoured to clarify the details. Given that these 'States' were imagined as essentially conterminous with the territories of 'uncontaminated' tribes, it was proposed that Government Residents would be appointed, and federal resources be provided, to assist in the inevitable growth of the states toward the conditions of modern life. Furthermore, they thought that educated Aboriginal people, like David Unaipon or David Noble, could be engaged to 'assist' in their founding. In consideration of Aboriginal people who had already been dispossessed of their land, it was suggested that they be granted land in southern Australia to develop their own states. ${ }^{46}$ As utopian as this must have sounded at the time, there were two core principles that set the league's agenda apart from that of other advocacy groups, and especially the AFA: the demand that Aboriginal people be given their land, and that they be allowed to manage their own affairs.

In 1926, the proponents of the plan formed themselves into the Aborigines' Protection League and held their first general meeting in the Adelaide Town Hall in late November that year. Their constitution stated that their aims were to promote the petition and eventually present it to federal parliament, work toward the establishment of the proposed 'state, or states', promote the 'wise and just treatment' of Aboriginal people, and 'prevent discrimination against them'. Herbert Basedow was elected president and J.C. Genders was made honorary secretary. The vicepresidents included four women, W.T. Cooke, J.A. McKay, A.K. Goode and A.I. Tomkinson, representatives of the Women's Non-Party Association; the natural scientists T.P. Bellchambers and S.A. White; C.E. Taplin, who appears to have ceased his association with the AFA; and the Ngarrindjeri polymath, David Unaipon. ${ }^{47}$

45 Register, 1 August 1925: 11.

46 Daylight, 31 March 1926: 16.

47 Advertiser, 27 November 1926: 11. 
Over the course of the following year, members of the association promoted the scheme and gathered signatures for their petition. They distributed their manifesto and petition in Adelaide and interstate, and collected signatures at stalls set up in city arcades. ${ }^{48}$ Supporters were interviewed on radio and in the press. ${ }^{49}$ They gave public talks to interested local groups such as the Justices' Association, the Theosophical Society and the Women's Non-Party Association. ${ }^{50}$ In June 1927, the Conference of Women's Associations passed a resolution in favour of the proposal and, in early 1928, their vice-president, Constance Cooke, spoke in favour of the plan in an address to the 'Anti-Slavery and Aborigines Protection Society' in London. ${ }^{51}$ While regularly cited in the press as a supporter of the Model State proposal, Unaipon was never a prominent spokesperson. He was most active in the league's early years; in August 1927, for instance, he presented a talk in support of the league in a series of broadcasts by radio station 5 CL. ${ }^{52}$

\section{Critics of the Model State proposal}

As the proposal became a subject of discussion in the press, Sexton, on behalf of the AFA, publicly and privately campaigned against it. A few days after Genders's 'Round Table Conference', Sexton wrote to the federal Minister for Home and Territories informing him of the 'fantastic scheme', and describing Genders as an 'unpractical dreamer' who had presented the scheme to them and, when he made no headway, resigned, 'for which we are devoutly thankful'. ${ }^{33}$ The committee of the AFA met at the end of March and drafted a formal response: they 'unanimously agreed' that the scheme 'was fantastic and impractical', that Aboriginal people would 'resent being lifted out of their own present environments' to be 'sent to a strange territory', and that the different tribes would not get along 'bringing about tribal quarrels and bloodshed'. What they preferred was the present system of 'setting aside reserves', which would be 'centres of real education and practical training' ${ }^{54}$ The Adelaide Advertiser endorsed the association's views, saying that the league's use of terms like 'State' and 'citizenship' were 'absurdly grandiose'. ${ }^{55}$

Genders took the lead in defending the proposal against its critics. Sexton's original criticism that the plan proposed to effectively 'herd' Aboriginal people onto an isolated reserve constituted the most frequently voiced condemnation of the scheme. In April 1927, the Western Australian Chief Protector, A.O. Neville,

48 Register, 22 February 1927: 8.

49 News, 15 August 1927: 10.

50 Advertiser, 14 March 1927: 18; Register, 21 April 1927: 3; Daylight, 30 June 1927: 195-210.

51 Daylight, 31 March 1928: 306.

52 News, 15 August 1927: 10.

53 Sexton to Secretary, Home and Territories Dept., 16 March 1925, AFA, Correspondence files, SRG 139/1/65.

54 AFA, Minutes, 31 March 1925, SRG 139/2-6.

55 Advertiser, 2 April 1925: 8. 
criticised it on these grounds, leading Genders to come out in the press and deny that this was what they proposed. ${ }^{56} \mathrm{He}$ was particularly aggrieved when the claim appeared again in the Australian Board of Missions Review. He responded in the May 1927 edition of Daylight, criticising Sexton, who by this time was the association's representative on the National Missionary Council, for deliberately encouraging this misrepresentation. ${ }^{57}$ In November, Genders went so far as to have his solicitor write to Archdeacon Bussell, then president of the association, charging that their claims were defamatory, and asking them to be withdrawn. ${ }^{58}$ As the campaign was reaching its head, the federal Minister for Home and Territories sought advice on the matter from the Chief Protector of the Northern Territory. Cecil Cook wrote that if the proposal sought to 'collect natives of assorted tribes together', then it was 'futile' and 'undesirable', but he noted that it did not propose this. He applauded the idealism of the proposal and thought that if applied to 'unspoilt natives', it might have some hope for success, but he would want to see a much more considered plan outlined. ${ }^{59}$

As Blackburn has noted, Aboriginal views of the Model State proposal were initially mixed, with significant opposition to it when it was presented, as the AFA characterised it, as a plan to remove Aboriginal people from their districts. ${ }^{60}$ For instance, an Aboriginal deputation to the Premier of Western Australia in 1928, believing the plan would entail forced removals, expressed opposition the idea. William Harris said that if a native State is provided nearly as many soldiers and police as there are Aborigines will be required to keep them there'. ${ }^{61}$ The allegiance of one of the league's most prominent Aboriginal supporters, David Uniapon, also shifted over time. Although a member of the league's inaugural general committee, Uniapon supported a motion opposing the idea at the annual general meeting of the AFA in $1928 .{ }^{62}$ While accepting that people's views change, it is nonetheless a fact that he had close links with Rev. John Sexton, who often quoted his views, and was to some extent reliant on the association for financial and moral support. ${ }^{63}$

The petition, signed by 7,113 people, was eventually tabled in federal parliament on 20 October 1927, but its introduction was overshadowed by a broader debate about Aboriginal welfare. A recent massacre in the Kimberley region of Western Australia, concerns about the treatment of mixed descent children in the Northern

\footnotetext{
56 News, 12 April 1927: 2.

57 Daylight, 24 May 1927: 186.

58 Various letters between Genders's solicitor N.A. Webb and the AFA between November 1927 and January

1928, AFA, Correspondence files, SRG 139/1/65.

59 C. Cook to Minister for Home and Territories, 3 September 1927, 'Model Aboriginal State', NAA A1, 1932/4262.

60 Blackburn 1999: 174-75.

61 West Australian, 10 March 1927: 18.

62 AFA, Minutes, 28 February 1928, SRG 139/2-6.

63 Markus 1990: 179-84.
} 
Territory, and questions about the role of missions led the government to discuss establishing a nationwide royal commission. As the debate unfolded over the last quarter of the year, the South Australian member for Hindmarsh, Norman Makin, pushed for the scheme to be considered. The responsible minister, already primed by Sexton, peremptorily dismissed it, referring to the opposition of the state's Advisory Council, and unnamed missionary associations. ${ }^{64}$ As debate on the proposed inquiry progressed, and it became clear that a smaller-scale inquiry into the treatment of 'Aboriginal and half-caste' people in the Northern Territory would go ahead, another South Australian member, Parsons, got an agreement that the Model State proposal would at least be included in its terms of reference. ${ }^{65}$

\section{The evolution of the campaign}

Frustrated by the federal government's failure to seriously consider their petition, the league took their appeals closer to home and organised a conference with members of state parliament on 31 May 1928. Only a handful of members attended the meeting, but it gave the league an opportunity to present their case in detail. Genders outlined their proposal and argued that there were essentially two policy alternatives before the public: that of the missionaries who sought large grants of money to 'pursue their old plans of "control" ... [through] "compulsory segregation", or that of the league which supported the right of Aboriginal people 'to manage their own affairs in their own communities along their own lines'. That afternoon they also presented their scheme to South Australian Senator A.J. McLachlan. After hearing them out, the senator assured them that their petition would not be overlooked, but, much to Genders's chagrin, repeated the criticism that Aboriginal people would object to being herded into a place away from their own districts. In June they approached the government again, this time with a smaller-scale, but more specific, proposal. They requested the minister to set aside an area of land on Eyre Peninsula in perpetuity as a native territory for the detribalised full-bloods and half-castes of the State to be governed under a Constitution by themselves'. The minister responded by saying that they did not possess land suitable for those purposes, but also that the 'Council of Aborigines' thought the plan impracticable. Genders later castigated the minister for being unable to correctly name his own department's Aborigines 'Advisory Council', scoffing at the idea that it was a 'Council of Aborigines' when it was made up mostly of AFA representatives who had their own agenda to push. ${ }^{66}$

64 Commonwealth Parliamentary Debates, 13 and 20 October 1927.

65 Commonwealth Parliamentary Debates, 2 November 1927.

66 The details of these meeting were reported at length in the 30 June 1928 issue of Daylight. 
Part of that agenda included expanding their missionary activity in Central Australia. An approach had already been made to the Advisory Council in 1925 to establish a mission on or near the North-West Reserve, but it had been rejected on the advice of the Chief Protector. ${ }^{67}$ In 1928, a celebrity missionary, Huston Edgar, famed for his mission to Tibet, was in Australia on a speaking tour. Sexton invited him to join E.E. Kramer's Camel Caravan to report on the condition of Aboriginal people in the North-West Reserve. ${ }^{68}$ On the party's return, accounts of the expedition were reported prominently in the press and the association published Edgar's report and ensured that it was widely distributed. Edgar condemned the 'leave him alone' policy, and described the 'uncontaminated tribes' of the region as 'crude, cruel and disgusting'. How, he asked, were they to be saved? It was the responsibility of the government, in conjunction with the missionary, to introduce them to 'British culture and Christianity', to 'instruct, control' and 'protect' them. ${ }^{69}$ Genders, on hearing reports about Kramer and Edgar's expedition, wrote that he looked forward to the time when the Reserve would be governed entirely by Aboriginal people themselves, and he hoped that the AFA might fund a university or a college in the new state. ${ }^{70}$

In March 1928, J.W. Bleakley, the Queensland Chief Protector, was appointed to conduct the federal inquiry into the management of Aboriginal people in Central and Northern Australia, and his report was released in February 1929. It was a detailed report that made recommendations on a wide range of issues such as the establishment of reserves, the treatment of 'half-castes', labour conditions and missions. It briefly dealt with the Native State, rejecting it as 'fantastic and impracticable'. ${ }^{71}$ To assess public opinion, C.L.A. Abbott, the Minister for Home and Territories, organised a conference of 'interested parties' in Melbourne to discuss the report. Held on 12 April 1929, it included delegates from all over Australia. South Australiass delegates included Henry Sexton, representing the AFA, and J.C. Genders, representing the Aborigines' Protection League (APL). ${ }^{72}$ Both organisations prepared submissions in advance. The AFA put forward a recommendation that the three Central Reserves be merged and put under federal control. They wanted a 'government settlement for the civilizing of the natives' be established where, under the supervision of a superintendent and assistants, Aboriginal people might be taught stock work. Finally, consistent with policy articulated at the National Missionary Conference, they insisted that missionaries should be appointed to

\footnotetext{
67 Advisory Council of Aborigines, Minutes, Vol. 1, 1918-1927, 1 September 1925, GRG 52/12/1.

68 'Exploration of Reserves in Central and Western Australia, Mr. J. H. Edgar and Mr. Kramer', AFA, Correspondence files, SRG 139/1/124/1928.

69 J. Huston Edgar, Exploration of the Great Reserves: Set apart for the Aborigines of South and Central Australia.

The report was published in the Register in September 1928 and in the AFA, Annual Report, 1928: 21-36.

70 Daylight, 30 June 1928: 344.

71 Bleakley 1929: 30.

72 Advertiser, 15 April 1929: 15.
} 
'assist in civilizing the natives', teach them to 'respect law and order' and 'give up cruel customs and practices'. ${ }^{73}$ His plan was for the Great Reserve to be transformed into a super-sized government station.

The APL also put a proposal to the conference, a further elaboration of their Model State proposal. Genders put forward the following motion:

That to the nomadic tribes who still have their tribal governments intact, land, taking the aboriginal boundaries, be allotted in perpetuity, and that they be allowed to govern it as far as they are able with the assistance of teachers and others, and that no white person should be allowed into the territory without a permit. ${ }^{74}$

Constance Cooke seconded the motion, but no one else supported it. Minister Abbott, wanting to move the discussion on to other matters, commented 'I think you are a little ahead of your time, Mr Genders'. ${ }^{75}$ In a later presentation to the APL about the proceedings of the conference, Genders criticised the vested interest of station owners, missionaries for hanging on to 'old-fashioned ideas' and the Australian Board of Missions for supporting 'compulsory segregation', and concluded that it was time for Aboriginal people to be allowed to solve the 'aboriginal problem' in their own way. ${ }^{76}$

One of the few actions to come out of the conference was the recommendation that the three Central Reserves be combined and placed under federal control. Sexton was triumphant, reporting back to the association's members that their proposal had received the 'unanimous' support of the conference. ${ }^{77}$ In coming months, correspondence on the issue was exchanged between the three governments, and it was decided that a meeting to discuss the takeover would be held in Adelaide. However, with the impact of the Great Depression deepening, it was mutually agreed to indefinitely defer the matter. ${ }^{78}$ Genders admitted leaving the conference 'disheartened'. ${ }^{79}$ While he never gave up on the idea of the Model State, the league increasingly directed its energies to other matters.

73 'Reserves in Central Australia', reproduced in AFA, Annual Report, 1929.

74 Conference of Representatives of Missions, Societies, and Associations interested in the Welfare of Aboriginals to consider the Report and Recommendations submitted to the Commonwealth Government by J. W. Bleakley

Esq., Report of Debates, Commonwealth of Australia, 12 April 1929: 11.

75 Conference of Representatives: 12.

76 Genders 1929, Report to the State Executive: 1-5.

77 AFA, Annual Report, 1929: 10.

78 Premier of SA to Premier of WA, 6 October 1930, Commissioner of Public Works, Correspondence files, GRG 23/1/1917/643.

79 Genders 1929, Report to the State Executive: 10. 


\section{The league's advocacy of land rights and self-determination}

Although the Model Aboriginal State was the league's marque issue, it involved itself in a range of other matters concerning Aboriginal rights and welfare, and almost invariably took a contrary position to the AFA. There were a number of key ideas and principles that emerge from the league's public statements. The first of these was a baseline position that Australia had failed to honour its historical obligations, and needed to make amends. In support of these claims, members would point to the state's founding proclamation that promised to protect Aboriginal rights and welfare, and Governor Gawler's ostensible defence of Aboriginal rights to land in the early years of settlement. ${ }^{80}$ As the Model State proposal itself demonstrates, land was identified as the crucial issue. In the published response to the Bleakley report, Genders made his most impassioned call for Aboriginal rights to land. He declared that whites had overrun their hunting grounds and reduced them to landless proletarians', and that Aboriginal people wanted 'some of the land back that has been stolen' from them. A leading plank of the league's proposal, he wrote, was that 'legal ownership of sufficient suitable land be transferred from the Crown to the Aborigines without power of alienation'. This, he pointed out, was not contained in Bleakley's recommendations, nor did it have a place in the 'missionary propaganda' of groups like the AFA. ${ }^{81}$

Following on from this recognition of dispossession was a claim that 'existing policy' was a failure and that something new needed to be tried. Pushed to be more precise about what the 'existing policy' actually was, Genders usually referred to the segregation of Aboriginal people on mission-run reserves or government stations. He criticised the 'well-intentioned', but 'mistaken approach of government and missionaries who instituted a system of control, control, control ...' ${ }^{82} \mathrm{He}$ condemned the National Missionary Council's policy of 'compulsory segregation' as 'unrighteous' and 'probably illegal', ${ }^{83}$ and asserted that the 'dominance over and repression of the aboriginals in the past has not given them the right inspiration for their progress' ${ }^{84}$ On a number of occasions, he personalised the attack by citing as a failure the AFA's 70 years of management at the Point McLeay mission. ${ }^{85}$ Furthermore, he criticised their influence on the Advisory Council. Writing in January 1928, he pointed out that all members of the Advisory Council, with one exception, were also members of the AFA. He could not think of a 'single' thing

80 See, for instance, Daylight, 28 February 1925, 31 March 1926; Observer, 28 August 1926; Advertiser, 22 October 1930; Genders 1937.

81 All quotes from Genders 1929, Statement by the Aborigines' Protection League: 2.

82 Daylight, 30 June 1928: 340.

83 Daylight, 31 December 1927: 271.

84 Daylight, 31 March 1928: 306.

85 Daylight, 31 October 1927: 246. 
that the council had done to give 'justice to our natives', but it nonetheless chose to interfere 'in a lot of matters which should not concern it', citing the 'iniquitous Act (now suspended) allowing native children to be taken from their parents'. ${ }^{86}$ As well as opposing the practice of child removal, it was a plank of the league's policy that they oppose all forms of discrimination. ${ }^{87}$

When Genders argued that they should be allowed to 'work out their destinies in their own self-governing communities', he was unequivocally advocating selfdetermination, albeit in the language of the day ${ }^{88}$ Genders looked to other models to give legitimacy to his proposal. Writing in 1927, he suggested that their proposed Model State might 'produce another Liberia', or African-American colony like Dearfield in Colorado. ${ }^{89}$ Lady Symon, wife of the eminent constitutional lawyer and, like her husband, a supporter of the league, described their aims as 'Home Rule for Australian Aborigines'.$^{90}$ By 1930, Genders was invoking Jan Smuts's South African policy of 'separate development' as a possible model. ${ }^{11}$ Writing in 1937, at about the time he resigned from the league because of growing ill-health, he cited the African policy of 'indirect rule' as the ideal approach for the way it 'involves the co-operation of the African in his own development'. He went on to observe, when 'we have learnt not to discriminate between the colour of the skin' and when through "Indirect rule" the Australian Aborigines has achieved national pride with his own Government, Chiefs, etc., has his own universities ... then it will be time to talk about assimilation'. ${ }^{22}$

The broad principle of self-determination underscored the nature of the league's advocacy politics and set it sharply against the position of the AFA. From the very outset, the league advocated that representatives of their proposed states should have seats in federal parliament. When Cooper's petition calling for reserved seats in federal parliament was circulating in the mid-to-late 1930s, the league was supportive, but Sexton was unimpressed. He believed that the 'petition' would 'stain the good reputation of Australia', and dismissed the signatories as 'mainly people of mixed blood and not content like the old aborigines to accept their fate in the old uncomplaining spirit'. ${ }^{93}$ In 1929, the league passed a resolution that Aboriginal people be 'represented on all Boards, Councils, Commissions, etc. relating to their affairs' ${ }^{94}$ This was a position they reiterated in 1936 when there were discussions about replacing the Advisory Council with a newly proposed board. Sexton spoke

86 Daylight, 31 January 1928: 283.

87 Advertiser, 27 November 1926: 11.

88 Daylight, 31 March 1928: 306.

89 Register, 8 June 1927: 7.

90 Daylight, 31 August 1928: 366.

91 News, 13 March 1930: 11.

92 Genders 1937: 3; Silverstein 2011: 97.

93 Quoted in the Advertiser, 27 October 1937: 25.

94 Advertiser, 19 January 1929: 13. 
out against this idea, saying that members of the board should be people 'really interested in the welfare of the Aborigines', people with 'education, experience and a knowledge of racial problems'. These were skills, he said, that 'would preclude Aborigines having a seat on the Board'. 95

The league, as was noted earlier, appointed David Unaipon to the inaugural committee, and sought to encourage Aboriginal support of their activities. In 1928, 'Narrunga Johnny' and John Bews, from the Point Pearce government station, and George Rankine, formerly of Point McLeay, all expressed support for the league's activities. ${ }^{96}$ In February, Genders put the proposal to a Constitution Commission, which was in Adelaide to take evidence on the question of federal control of Aboriginal matters, and George Rankine gave evidence in support. He approved of the proposal that a 'large area of land somewhere in Arnhem Country' be set aside for 'the primitive natives now residing there'. He also supported the newer idea of a 'Territory for all educated Aboriginals living in the lower part of South Australia':

Such aboriginals be given the power to govern and direct the management of the Territory. The absolute failure of the Mission Stations now in existence is to my mind the reason why the Constitution drawn up by the Aborigines' Protection League is an ideal one ... ${ }^{97}$

Narrunga Johnny wrote that the 'model state proposed for aborigines is an exceptionally kind and thoughtful proposition'. ${ }^{98}$ In expressing their support for the Model State proposal, these men also used the opportunity to protest more generally against their treatment. Bews, a First World War veteran, complained that the policy of 'protection' did not protect them but treated them like children. Narrunga Johnny argued much the same thing, writing that the 'aboriginal laws ... degrade rather than uplift us', and that the Act should be abolished. Rankine described the mission stations as a 'farce' and called upon Aboriginal people to be given the power to govern and direct their own affairs. ${ }^{99}$ They wanted land and the freedom to 'work out their own career' or, as Rankine put it, the chance to live 'in their own community'. Genders reproduced their correspondence in Daylight, and applauded their forthright views. ${ }^{100}$

By September 1926, the New South Wales-based AAPA had begun corresponding with the league. E. McKenzie Hatton, the secretary of the AAPA, pointed out that all 'officers of the Association, were Aboriginal', and that it was 'the people's own movement and things are done from the viewpoint of the Aboriginal which is a vital

95 Genders and Sexton quoted in the News, 14 July 1936: 5.

96 Advertiser, 17 January 1928: 14 and 24 January 1928: 15; Register, 28 January 1928: 14.

97 George Rankine's evidence to the Consitution Commission, quoted in Daylight, 29 February 1928: 292.

98 Advertiser, 17 January 1928: 14.

99 Evidence to the Constitution Committee, reproduced in Daylight, 29 February 1928: 292.

100 Daylight, 29 February 1928: 294. 
starting point when beginning to help them'. ${ }^{101}$ In March 1928, Genders published more correspondence from the association, which endorsed their proposal and expressed solidarity: 'the time has come for the aboriginal to make a definite stand for citizen's rights and have a voice in the welfare of our own country'. ${ }^{102}$ Shortly afterwards, probably inspired by contact with this interstate organisation, and with initial assistance from the league, the Australian Aboriginal Association was formed. ${ }^{103}$ Advertisements in Daylight called upon Aboriginal people interested in joining to contact D. Roper who was listed as 'Secretary Pro. Tem'. ${ }^{104}$ Roper, who had previously been a superintendent at Point Pearce, was at this time financial secretary of the APL. By June, a Point Pearce Branch of the Australian Aboriginal Association had been formed with P. Williams as president and Mark Wilson taking over from Roper as secretary. The deputation that put the 'Eyre Peninsula Model State' proposal to the South Australian Parliament in June 1928 included Wilson, Williams and Rankine as representatives of the Australian Aboriginals' Association. ${ }^{105}$

While Aboriginal people had long been active in campaigning for their rights, the Australian Aboriginal Association appears to have been the first formal Indigenous political organisation established in South Australia. ${ }^{106}$ Relatively little seems to have been recorded about its activities, but it was still active in the 1930s as the Australian Aborigines Union, under the presidency of Robert Wanganeen. In 1933, it declared that the two central objectives of the association were to organise so that they may have 'a voice in the all-important question of the better treatment of aborigines' and to get parliament to formulate a scheme whereby 'civilized and educated natives could become a valuable asset to the land that rightfully belongs to them'. ${ }^{107}$ Two years later, Wanganeen and 97 other Point Pearce residents petitioned the government, complaining that the 'white race' was 'occupying our lands' and treating them as 'paupers and outcasts'. They called upon the government to 'allow a person of their blood' to represent their interests on any proposed government board. ${ }^{108}$ As Raftery notes, while Wanganeen was assured that the matter would receive the government's attention, the view of Protector M.T. McLean was that an Aboriginal person should not be included on the proposed board. ${ }^{109}$

101 Daylight, 30 September 1926: 89.

102 Daylight, 31 March 1928: 305.

103 Maynard 2008: 81-86, 125-28.

104 Daylight, 30 April 1928.

105 Daylight, 30 June 1928: 340.

106 Raftery 2006: 171-73.

107 Chronicle, 21 December 1933: 2; Raftery 2006: 171-72.

108 Cited in Raftery 2006: 171-72.

109 Raftery 2006: 172. 
In the late 1920s and early 1930s, a number of episodes of violence in Central and Northern Australia gave advocacy groups like the Aborigines' Protection League and the AFA great cause for concern. ${ }^{110}$ The AFA, while condemning the killings at Coniston in Central Australia, nonetheless hedged its criticism by pointing to the 'lawlessness' of the Aborigines, ${ }^{111}$ and asking for 'sympathy to be extended to the hard-working outback settler who lose their stock by the natives spearing them'. ${ }^{112}$ When international criticism of the treatment of Aboriginal people began to be reported in the press, Sexton's first response was to defend the country's reputation and ask why there was no reference to the 'fine service' that organisations like his were doing. ${ }^{113}$ The APL, on the other hand, suggested that Australia's treatment of Aboriginal people be taken before the British Privy Council. It was also proposed that they hold a Moot Court to 'bring our white civilisation before the bar of justice'. ${ }^{114}$ Basedow was quoted in the press as saying that the hearing would consider the confiscation of tribal lands, the uncounted destruction of lives, laws and customs, the defilement of woman and the enslavement of men, and the country's failure to assist in Aboriginal people's transition from nomadic to settled life. ${ }^{115}$ Genders wrote to the AFA asking if they would participate, but they declined on the grounds that they saw no practical purpose in the event. ${ }^{116}$ Although Genders had the interest of the Justices' Association, there is no evidence that the Moot Court was ever held.

An incident that occurred in 1928 serves to highlight the extent to which the agendas of both organisations reflected fundamentally different attitudes toward Aboriginal people and culture. When reports circulated in 1928 that sacred Churingas had been stolen from Aboriginal people in Central Australia, Basedow expressed outrage, writing that Aboriginal people were not 'heathen', and the theft of such a 'sacred relic' was 'little remote from sacrilegious vandalism'. ${ }^{117}$ Sexton and the AFA were more sanguine about it, reporting that the stones were not sacred, had probably been sold to the tourists and no further action was necessary. ${ }^{118}$ Members of the APL were influenced by contemporary anthropological theory, they praised traditional Aboriginal laws and customs as the 'moral' glue that held their communities together, and they sought to protect Aboriginal people still living traditionally from forced cultural change. For Sexton, Aboriginal people were not moral, they were fallen, and it was his Christian duty to rescue them. He endorsed the views of missionary Edgar, that Aboriginal people were 'crude, cruel and disgusting', and that they be

110 Biskup 1973: 84-86; Powell 1996: 156-58.

111 AFA, Annual Report, 1929.

112 AFA, Annual Report, 1928.

113 AFA, Minutes, 16 November 1932, SRG 139/2; see also Mail, 17 December 1932.

114 Advertiser, 22 October 1930: 8; News, 13 March 1930: 17.

115 Advertiser, 22 October 1930: 8.

116 AFA, Minutes, 27 March 1930, SRG 139/2-6.

117 Daylight, 31 May 1928: 330.

118 AFA, Annual Report, 1927: 9. 
taught 'British culture and Christianity'. Where the APL saw European influence as the cause of Aboriginal people 'dying out', Sexton argued that they carried 'within themselves the seeds' of their own 'decay'.

In the first decade of its existence, while Basedow was president, the APL had largely been guided by Genders and the Model State campaign. However, when Basedow passed away and was replaced by Charles Duguid, their focus shifted to the 'Great Central Reserve' and the idea of a 'Medical Mission'. Duguid was elected president of the league in June 1935, having been elected the first lay Moderator of the Presbyterian Church just a few months before. ${ }^{119}$ Duguid had no background in Aboriginal policy, was not a missionary, but his views were informed by anthropology. Like fellow league members White, Basedow and Jennison, he was concerned at the impact that spreading settlement was having on the residents of the North-West Reserve. In 1937, with the support of the Protector of Aborigines and the Advisory Council, Charles Duguid was given authority to establish a 'Christian Anthropological Mission' on the eastern border of the North-West Reserve. ${ }^{120}$ The new head of the Advisory Council at this time was J.B. Cleland, Chairman of the University of Adelaide's Board for Anthropological Research. Cleland had earlier advocated the establishment of a 'buffer zone' to be managed by a 'neutral body', and Duguid's 'Medical Mission' appears to have satisfied that criteria. ${ }^{121}$ This was not the sort of missionary presence that Edgar and Sexton had advocated in 1928, but something new. However, it was broadly in accord with the principles of the league in not advocating forced cultural change, promoting respect for traditional Aboriginal culture and assistance in their transition to settled life. Independent of these developments, the anthropologist Donald Thompson was suggesting something similar for the Northern Territory. In a report on Aboriginal policy, presented to the federal government, in December 1937, he suggested that mission stations be located at the boundary of reserves, serving essentially as 'buffers'. ${ }^{122}$ Duguid applauded the idea as being consistent with the approach he was taking, while Sexton again dissented, arguing that missions should be at the heart of reserves so that Aboriginal people could be educated and weaned off their superstitions. ${ }^{123}$

In 1938, Genders, now 80 years of age, stepped down as secretary of the league citing ill-health. The year before, he produced a document summarising his philosophy, at the heart of which was still a proposal for Aboriginal states. The league he founded had moved on from Genders's idée fixe, but the broad, underlying principles were still there, although less ambitious in scope and expressed in more temperate language. In a discussion of the league's principles during a 1940 committee meeting, they

119 Duguid 1982: 107-8.

120 Edwards 2012: 12-14.

121 Gray 2007: 55-56.

122 Thompson 1937: 7.

123 Advertiser, 31 December 1937: 18. 
agreed that the league would be 'non-political, non-sectarian', that its 'main duty' would be to 'see that suitable land is set aside for the aborigines', and that the 'League recognises the aborigine's right to retain his native culture'. ${ }^{124}$ The APL continued to speak out on matters concerning Aboriginal welfare, most notably in 1939 and 1940 when the prospect of mining again threatened the integrity of the Great Central Reserve. Its energies, however, were diminishing. In 1939, the new secretary noted that the original members were dropping away and nothing was being done to attract younger people. The league folded in 1946, with many of its members giving their support to the newly established Aborigines Advancement League of South Australia. ${ }^{125}$

\section{Conclusion}

In the early 1920s, the AFA was the sole Aboriginal advocacy organisation in South Australia. Fundamentally a missionary group, it dominated public discussion about Aboriginal welfare, and helped shape the protection policy of the era through its dominance on the Advisory Council for Aborigines. The APL, while it had supporters drawn from religious organisations, was more secular in its outlook. The 'Model Aboriginal State' proposal was, as Silverstein has commented, 'too much to have hoped for it', and 'not a plan that the settler colonial state was likely to implement'. However, in its relatively short life, the league promoted principles that challenged the established policy of 'protection', by advocating land rights and self-determination. The mantra of the APL was that Aboriginal people should have the right to 'determine their own destinies in their own communities'. By the time of the Initial Conference of State and Federal Authorities in Canberra in 1937, protection policy had essentially run its course, but the idea of self-determination was still 'fantastic and impracticable'. In announcing that 'the destiny of the natives of aboriginal origin, but not of the full-blood, lies in their ultimate absorption by the people of the commonwealth', the conference was moving towards the new era of assimilation. ${ }^{126}$ In 1939, Minister for the Interior Jack McEwen announced his 'New Deal for Aborigines', which promised the gradual 'uplift' of Aboriginal people and a path to 'citizenship', transitioning Aboriginal people from their 'nomadic tribal state' to life in 'a civilized community'. This was a process, as McGregor observes, in which Aboriginal people had 'little involvement and less influence', and 'arguably ... intensified administrative intrusions into Aboriginal lives' ${ }^{127}$ The 'protection era' was over, but self-determination was still 'a little ahead of its time'.

124 Aborigines Protection' League, Minutes, February 1940, SRG 250/1.

125 Kerin 2017: 118-21.

126 Aboriginal Welfare: Initial Conference of Commonwealth and State Aboriginal Authorities, 1937: 3.

127 McGregor 2011: 34. 


\section{References}

\section{Primary sources}

\section{Newspapers}

The Advertiser (Adelaide)

Chronicle (Adelaide)

Daylight

The Mail (Adelaide)

News (Adelaide)

The Register (Adelaide)

The West Australian

Aboriginal Welfare: Initial Conference of Commonwealth and State Aboriginal Authorities, held in Canberra, 21st to 23rd April 1937, L.F. Johnston, Commonwealth Government Printer, Canberra, 1937.

Aborigines Advancement League, Minutes of the Aborigines' Protection League, 1938-40, 1 vol., SRG 250/1, State Library of South Australia.

Aborigines' Friends' Association 1912-39, Annual Reports, The Association, Adelaide.

Aborigines' Friends' Association, Correspondence, SRG 139/1, State Library of South Australia.

Aborigines' Friends' Association, Minutes of the General Committee, SRG 139/2, State Library of South Australia.

Advisory Council of Aborigines, Minutes, Vol. 1, 1918-1939, GRG 52/12, State Records of South Australia.

An Act to make provision for the better Protection and Control of the Aboriginal and Half-Caste Inhabitants of South Australia, No. 1048 of 1911.

Basedow Papers, Newspaper Cuttings, Vol. 5, PRG 324/1/5, State Library of South Australia.

Bleakley, J.W. 1929, The Aboriginals and Half-Castes of Central Australia and North Australia, Commonwealth of Australia: Government Printer, Victoria.

Commissioner of Public Works, Correspondence files, GRG 23/1, State Records of South Australia.

Conference of Representatives of Missions, Societies, and Associations interested in the Welfare of Aboriginals to consider the Report and Recommendations submitted to the Commonwealth Government by J. W. Bleakley Esq., Report of Debates, Commonwealth of Australia, 12 April 1929. 
Genders, J.C. 1929, Australian Aboriginals, A Statement by the Aborigines' Protection League explaining its basic principles and proposals, Adelaide, bound with Report to the State Executive of the Aborigines' Protection League, Adelaide, 26 June 1929, State Library of South Australia.

Genders, J.C. 1937, The Australian Aborigines, Typescript Report, 4 January 1937, State Library of South Australia.

Huston Edgar, J. 1928, Exploration of the Great Reserves: Set apart for the Aborigines of South and Central Australia, reproduced in the Aborigines' Friends' Association, Annual Report: 21-36.

'Proposed Model Aboriginal State', NAA A1, 1932/4262. National Archives of Australia.

Protector of Aborigines, Annual Reports, South Australian Parliamentary Papers, 1908-1940.

South Australia, Royal Commission 1913, Progress Report of the Royal Commission on the Aborigines, 7 October 1913, South Australian Parliamentary Papers, No. 26 of 1913.

South Australian Government Gazette

South Australian Parliamentary Papers

Thompson, Donald 1937, Recommendations of the Policy in Native Affairs in the Northern Territory of Australia, Government Printer, Canberra.

\section{Secondary sources}

Attwood, Bain 2003, Rights for Aborigines, Allen \& Unwin, Sydney.

Biskup, Peter 1973, Not Slaves, Not Citizens: The Aboriginal Problem in Western Australia, 1898-1954, University of Queensland Press, St Lucia.

Blackburn, Kevin 1999, 'White agitation for an Aboriginal state in Australia (1925-29)', Australian Journal of Politics and History 45(2): 158-79. doi.org/10.1111/1467-8497. 00060 .

Burgess H.T. (ed.) 1907, The Cyclopedia of South Australia, Cyclopedia Co., Adelaide.

Duguid, Charles 1982, The Doctor and the Aborigines, Rigby Ltd, Adelaide.

Edgar, Suzanne 1988, 'Sexton, John Henry (1863-1954)', Australian Dictionary of Biography, National Centre of Biography, The Australian National University, adb.anu. edu.au/biography/sexton-john-henry-8390/text14709, published first in hardcopy 1988 (accessed online 1 February 2017).

Edwards, Bill 2012, Mission in the Musgraves: Ernabella Mission 1937: A Place of Relationships, Uniting Church Historical Society (SA), Adelaide.

Foster, Robert 2000, “"Endless trouble and agitation”: Aboriginal activism in the protectionist era', Journal of the Historical Society of South Australia 28: 15-27. 
Gray, Geoffrey 2007, A Cautious Silence: The Politics of Australian Anthropology, Aboriginal Studies Press, Canberra.

Jenkins, Graham 1976, 'The Aborigines' Friends' Association and the Ngarrindjeri People', MA thesis, University of Adelaide, Adelaide.

Kerin, Rani 2017, 'Adelaide-based activism in the mid-twentieth century: Radical respectability', in Colonialism and Its Aftermath: A History of Aboriginal South Australia, Peggy Brock and Tom Gara (eds), Wakefield Press, Adelaide.

Markus, Andrew 1990, Governing Savages, Allen \& Unwin, Sydney.

Markus, Andrew 2000, 'Kramer, Ernest Eugene (1889-1958)', Australian Dictionary of Biography, National Centre of Biography, The Australian National University, adb.anu. edu.au/biography/kramer-ernest-eugene-10763/text19083, published first in hardcopy 2000 (accessed 1 February 2017).

McGregor, Russell 2011, Indifferent Inclusion: Aboriginal People and the Australian Nation, Aboriginal Studies Press, Canberra.

Maynard, John 2008, Fight for Liberty and Freedom: The Origins of Australian Aboriginal Activism, Aboriginal Studies Press, Canberra.

Powell, Alan 1996, A Far Country: A Short History of the Northern Territory, Melbourne University Press, Melbourne.

Raftery, Judith 2006, Not Part of the Public: Non-Indigenous Policies and Practices and the Health of Indigenous South Australians, 1836-1973, Wakefield Press, Adelaide.

Raynes, Cameron 2009, The Last Protector: The Illegal Removal of Aboriginal Children from Their Parents in South Australia, Wakefield Press, Adelaide.

Roe, Michael 1986, 'A model Aboriginal state', Aboriginal History 10: 40-44.

Silverstein, Ben 2011, 'Indirect rule in Australia: A case study in settler colonial difference', in Studies in Settler Colonialism: Politics, Identity and Culture, Fiona Bateman and Lionel Pilkington (eds), Palgrave MacMillan, London. 
This text is taken from Aboriginal History, Volume 42, 2018, edited by Ingereth Macfarlane, published 2018 by ANU Press, The Australian National University, Canberra, Australia.

doi.org/10.22459/AH.42.2018.04 